\title{
Elongator Plays a Positive Role in Exogenous NAD-Induced Defense Responses in Arabidopsis
}

\author{
Chuanfu An, Yezhang Ding, Xudong Zhang, Chenggang Wang, and Zhonglin Mou \\ Department of Microbiology and Cell Science, University of Florida, P.O. Box 110700, Gainesville, FL 32611, U.S.A. \\ Submitted 7 January 2015. Accepted 21 February 2016.
}

Extracellular NAD is emerging as an important signal molecule in animal cells, but its role in plants has not been wellestablished. Although it has been shown that exogenous NAD ${ }^{+}$ activates defense responses in Arabidopsis, components in the exogenous $\mathrm{NAD}^{+}$-activated defense pathway remain to be fully discovered. In a genetic screen for mutants insensitive to exogenous $\mathrm{NAD}^{+}$(ien), we isolated a mutant named ien2. Mapbased cloning revealed that IEN2 encodes ELONGATA3 (ELO3)/AtELP3, a subunit of the Arabidopsis Elongator complex, which functions in multiple biological processes, including histone modification, DNA (de)methylation, and transfer RNA modification. Mutations in the ELO3/AtELP3 gene compromise exogenous $\mathrm{NAD}^{+}$-induced expression of pathogenesis-related (PR) genes and resistance to the bacterial pathogen Pseudomonas syringae pv. maculicola ES4326, and transgenic expression of the coding region of ELO3/AtELP3 in elo3/Atelp3 restores $\mathrm{NAD}^{+}$responsiveness to the mutant plants, demonstrating that ELO3/AtELP3 is required for exogenous NAD ${ }^{+}$-induced defense responses. Furthermore, mutations in genes encoding the other five Arabidopsis Elongator subunits (ELO2/AtELP1, AtELP2, ELO1/AtELP4, AtELP5, and AtELP6) also compromise exogenous $\mathrm{NAD}^{+}$-induced $P R$ gene expression and resistance to $P$. syringae pv. maculicola ES4326. These results indicate that the Elongator complex functions as a whole in exogenous $\mathrm{NAD}^{+}$activated defense signaling in Arabidopsis.

NAD and its derivative NADP are pyridine nucleotides serving as ubiquitous redox carriers and coenzymes in both anabolic and catabolic pathways (Noctor et al. 2006). In addition to participating in fundamental metabolic reactions, $\mathrm{NAD}(\mathrm{P})$ has been implicated in intracellular signaling by acting as ADP-ribose (ADPR) donors, acetyl group acceptors, or precursors for cyclic (c)ADPR and nicotinic acid adenine dinucleotide phosphate (NAADP) to trigger release of calcium $\left(\mathrm{Ca}^{2+}\right)$ from intracellular

C. An and Y. Ding contributed equally to this work.

Nucleotide sequence data can be found in the Arabidopsis Genome Initiative or GenBank/EMBL databases under the following accession numbers: ELO2/AtELP1 (At5g13680), AtELP2 (At1g49540), ELO3/AtELP3 (At5g50320), ELO1/AtELP4 (At3g11220), AtELP5 (At2g18410), AtELP6 (At4g10090), PR1 (At2g14610), PR2 (At3g57260), PR5 (At1g75040), and UBQ5 (At3g62250).

Corresponding author: Z. Mou; E-mail: zhlmou@ufl.edu

*The $\boldsymbol{e}$-Xtra logo stands for "electronic extra" and indicates that four supplementary figures, three supplementary tables, and supplementary methods are published online.

(C) 2016 The American Phytopathological Society compartments in different organisms (Bürkle 2001; Denu 2003; Hunt et al. 2004; Jacobson and Jacobson 1999; Lee 2001; Ziegler 2005). Upon environmental stress, cellular NAD(P) can be released into the extracellular compartment by active exocytosis or diffusion through transmembrane transporters in living cells or passive leakage across membrane in dying cells (Billington et al. 2006). Recent studies have established extracellular (e)NAD(P) as a signal molecule for diverse physiological and pathological responses (Billington et al. 2006; Judkins et al. 2006).

In animal cells, eNAD(P) is metabolized by ectoenzymes or perceived by cell-surface receptors or channels to activate downstream signaling pathways. CD38, CD157, and mono(ADP-ribosyl) transferases (ART) are $\mathrm{NAD}(\mathrm{P})$-metabolizing ectoenzymes located on the extracellular surface of the plasma membrane (Malavasi et al. 2006; Morabito et al. 2006; Partidá-Sánchez et al. 2007; Zolkiewska 2005). CD38 is a multifunctional enzyme that utilizes $\mathrm{NAD}(\mathrm{P})$ as substrates to produce the secondary messengers cADPR and NAADP (Ceni et al. 2003; De Flora et al. 2004; Krebs et al. 2005; Partidá-Sánchez et al. 2007). ART are glycosylphoshpatidylinositol-anchored or secreted ectoenzymes that utilize NAD to ADP-ribosylate lipid raft-associated signaling proteins (Bannas et al. 2005; Han et al. 2000; Nemoto et al. 1996; Seman et al. 2003). Furthermore, activation of the purinoceptor $\mathrm{P}_{2} \mathrm{Y}_{11}$ by eNAD functionally activates human granulocytes (Bruzzone et al. 2006; Moreschi et al. 2006) and interaction between eNADP and purinoceptors can cause contraction of mouse aorta (Judkins et al. 2006).

In plants, NAD and its derivatives have been shown to be involved in several signaling pathways that are mostly associated with stress tolerance or defense responses (Adams-Phillips et al. 2010; Berger et al. 2004; Djebbar et al. 2012; Dutilleul et al. 2003, 2005; Ford et al. 2010; Noctor et al. 2006; Pétriacq et al. 2013). Increasing intracellular NAD levels by overexpressing the bacterial NAD biosynthesis gene nadC leads to enhanced defense-gene expression and resistance to bacterial pathogens (Pétriacq et al. 2012), whereas mutations in the de novo NAD biosynthesis gene FLAGELLIN-INSENSITIVE4 compromise stomatal immunity (Macho et al. 2012). Moreover, changing intracellular $\mathrm{NAD}(\mathrm{H})$ levels by overexpressing AtNUDT6, which encodes an ADP-ribose/NADH pyrophosphohydrolase or knockout of AtNUDT6, AtNUDT7, or AtNUDT8 alters salicylic acid (SA)mediated defense responses (Adams-Phillips et al. 2008; Bartsch et al. 2006; Fonseca and Dong 2014; Ge et al. 2007; Ishikawa et al. 2010). Furthermore, we recently provided the first line of evidence that eNAD $(\mathrm{P})$ may play a signaling role in plant immunity (Zhang and Mou 2009). We showed that pathogen-induced hypersensitive response causes leakage of $\mathrm{NAD}(\mathrm{P})$ into the extracellular fluid at concentrations sufficient to induce pathogenesis-related $(P R)$ gene expression and disease resistance. More importantly, exogenous $\mathrm{NAD}(\mathrm{P})$-induced $P R$ gene expression appears to be associated with $\mathrm{Ca}^{2+}$ signaling and SA (Zhang and Mou 2009). However, NAD(P) 
treatment induces not only SA-dependent but also SA-independent $P R$ gene expression and disease resistance, suggesting that SA signaling is not the sole target for exogenous $\mathrm{NAD}(\mathrm{P})$ in activating defense responses (Zhang and Mou 2009).

Since no proteins with significant homology to animal CD38/CD157, ART, and purinoceptors have been identified in any available plant genome database (Sánchez et al. 2004; Zolkiewska 2005), it is not clear whether plants use similar mechanisms to process or perceive eNAD $(\mathrm{P})$ and to transduce eNAD(P)-activated signals (Hunt et al. 2004). Expression of the human NAD $(\mathrm{P})$-metabolizing ectoenzyme CD38 partially compromises systemic acquired resistance (SAR) in Arabidopsis (Zhang and Mou 2012), which strongly suggests that plants may use different mechanisms to perceive eNAD(P). Identifying components of the eNAD(P)-activated signaling pathway in Arabidopsis is, therefore, a crucial step for understanding these mechanisms. To this end, our recent identification of Arabidopsis mutants insensitive to exogenous $\mathrm{NAD}^{+}$(ien) revealed the Mediator complex subunits MED14/STRUWWELPETER (SWP) and MED16/SENSITIVE TO FREEZING6 (SFR6)/ INSENSITIVE TO EXOGENOUS NAD ${ }^{+} 1$ (IEN1) as downstream regulators that transduce exogenous $\mathrm{NAD}^{+}$-activated signals to the RNA polymerase II (RNAPII)-mediated transcription initiation (Zhang et al. 2012, 2013).

The transition from transcriptional initiation to elongation is associated with changes in the factors that are associated with RNAPII. Elongator (ELP) is originally identified as an interactor of hyperphosphorylated RNAPII, a marker of transcriptional elongation in yeast and is subsequently purified from mammalian and plant cells (Hawkes et al. 2002; Nelissen et al. 2010; Otero et al. 1999). A fully functional Elongator complex consists of two copies of each of its six subunits, with ELP1 and ELP2 serving as scaffolds for complex assembly, ELP3 being the catalytic subunit, and ELP4-ELP6 forming an accessory complex. Elongator has been shown to function in multiple cellular processes such as histone modification, exocytosis, $\alpha$-tubulin acetylation, zygotic paternal genome demethylation, and transfer RNA (tRNA) modification (Creppe et al. 2009; Hawkes et al. 2002; Huang et al. 2005; Okada et al. 2010; Rahl et al. 2005). Although the regulatory roles in both transcription and translation seem to be conserved, it becomes clear that Elongator has multiple kingdom-specific functions in diverse organisms (DeFraia and Mou 2011). In yeast, mutations in Elongator subunits cause resistance to the zymocin $\gamma$-toxin and sensitivity to salt, caffeine, and temperature (Jablonowski et al. 2001; Krogan and Greenblatt 2001; Otero et al. 1999). Elongator deficiency in humans results in defective neuron development, manifested as familial dysautonomia disease (Anderson et al. 2001; Slaugenhaupt et al. 2001).

The Arabidopsis Elongator complex also contains six subunits: ELONGATA2 (ELO2)/AtELP1, AtELP2, ELO3/AtELP3, ELO1/AtELP4, AtELP5, and AtELP6 (Nelissen et al. 2010). Mutations in ELO2/AtELP1, AtELP2, ELO3/AtELP3, ELO1/AtELP4, and AtELP6 lead to pleiotropic effects including hypersensitivity to abscisic acid, resistance to oxidative stress, severely aberrant auxin phenotypes, altered cell cycle progression, abnormal root development, and compromised disease resistance (Chen et al. 2006; Jia et al. 2015; Nelissen et al. 2005, 2010; Xu et al. 2012; Zhou et al. 2009). Additionally, AtELP2 and ELO3/AtELP3 have been shown to regulate the induction kinetics of defense genes of the SA pathway (DeFraia et al. 2010, 2013). Further characterization indicated that AtELP2 is an epigenetic regulator required for the bacterial pathogen Pseudomonas syringae pv. tomato DC3000/avrRpt2-induced rapid transcriptome reprogramming, likely by maintaining histone acetylation levels, modulating the genomic DNA landscape, and influencing pathogen-induced dynamic DNA methylation changes (Wang et al. 2013).
Here, we report another ien mutant, ien2/Atelp3-11, which was isolated in the previously described genetic screen (Zhang et al. 2012). Characterization of ien2/Atelp3-11 together with elo2/Atelp1, Atelp2, elo1/Atelp4, Atelp5, and Atelp6, mutants of the other five Elongator subunits, revealed that Elongator as a whole plays a positive role in exogenous $\mathrm{NAD}^{+}$-activated defense responses in Arabidopsis.

\section{RESULTS}

\section{The ien 2 mutation compromises exogenous} $\mathrm{NAD}^{+}$-induced $P R$ gene expression and disease resistance.

The ien 2 mutant was isolated in the previously described genetic screen (Zhang et al. 2012). After backcrossing twice with wild-type Columbia (Col-0) plants, the ien2 mutant was further analyzed. Compared with the wild-type Col-0, exogenous $\mathrm{NAD}^{+}$-induced expression of $P R 1, P R 2$, and $P R 5$ was significantly inhibited in the ien2 mutant plants (Fig. 1A). Consistent with the reduced $P R$ gene induction, $\mathrm{NAD}^{+}$-induced resistance to the bacterial pathogen $P$. syringae pv. maculicola ES4326 was also compromised in the ien2 plants (Fig. 1B and C). These results indicate that IEN2 plays an important positive role in exogenous $\mathrm{NAD}^{+}$-induced defense responses.

Morphologically, ien2 leaves were serrated, curly, and a lighter shade of green than the wild-type Col-0 (Fig. 1D), which is reminiscent of the previously described Elongator mutants (Chen et al. 2006; DeFraia et al. 2010, 2013; Nelissen et al. 2005, 2010; Zhou et al. 2009). Moreover, similarly to the Atelp2 and elo3/Atelp3 mutants (DeFraia et al. 2010, 2013), ien2 exhibited enhanced susceptibility to P. syringae pv. maculicola ES4326 (Fig. 1E and F), indicating that IEN2 also positively contributes to basal resistance against this bacterial pathogen.

\section{IEN2 encodes the Elongator subunit 3.}

During backcrosses with wild-type Col- 0 plants, we found that all $\mathrm{F}_{2}$ progeny with ien 2 morphology were susceptible to $P$. syringae pv. maculicola ES4326, indicating that the morphological and disease susceptibility phenotypes of ien 2 were caused by the same mutation or two tightly linked mutations. Additionally, the ien 2 morphology is controlled by a single recessive nuclear mutation, as the $\mathrm{F}_{1}$ progeny displayed wildtype Col- 0 morphology and the $F_{2}$ population segregated into wild-type-Col-0-like and ien2-like plants in a 3:1 ratio. We therefore used the morphological phenotype to map the ien2 mutation. To this end, we crossed ien2, which is in the Col-0 genetic background, to the polymorphic ecotype Landsberg erecta. The $F_{1}$ plants were selfed to produce an $F_{2}$ population. Linkage analysis of $107 \mathrm{~F}_{2}$ plants with ien 2 morphology placed the ien 2 mutation between the molecular markers CIW9 and CIW10 on chromosome 5 (Fig. 2A), an interval that contains the ELO3/AtELP3 gene (DeFraia et al. 2013). Further analysis did not find any recombinants for markers at the genetic loci At5g50270 and At5g50360 (Fig. 2A). Since ien2 morphologically resembled the previously described elo3-6 and Atelp3-10 mutants (Supplementary Fig. S1) (Nelissen et al. 2010; DeFraia et al. 2013), the ien 2 mutation might be located in ELO3/AtELP3 (At5g50320). To test this, the ELO3/AtELP3 coding region was amplified from ien 2 and was sequenced. A single base substitution of A for $\mathrm{G}$ was detected at the $5^{\prime}$ splice site of the sixth intron of At5g50320 (Fig. 2B). Based on the mutation, a cleaved amplified polymorphic sequences marker was developed to genotypically distinguish ien 2 from the wild-type Col-0 (Fig. 2C). To test whether the mutation affected mRNA splicing, wild-type Col-0 and ien 2 cDNA were amplified by polymerase chain reaction (PCR), using a pair of primers spanning the mutation site. As shown in Figure 2D, while a single band was amplified from the wild-type Col-0 cDNA, multiple bands with different sizes 
were amplified from the ien $2 \mathrm{cDNA}$, indicating that ien 2 is a new allele of elo3/Atelp3. Therefore, ien2 was renamed Atelp3-11 (Fig. 2B).

Next, we analyzed exogenous $\mathrm{NAD}^{+}$-induced $P R$ gene expression in two previously reported elo3/Atelp3 mutant alleles, elo3-6 and Atelp3-10 (DeFraia et al. 2013; Nelissen et al. 2010). Compared with the wild-type Col- $0, \mathrm{NAD}^{+}$-induced expression of PR1, PR2, and PR5 was also significantly reduced in elo3-6 and Atelp3-10 (Fig. 2E), indicating that mutations in ELO3/AtELP3 suppress $\mathrm{NAD}^{+}$-induced defense responses.

Finally, we tested $\mathrm{NAD}^{+}$responsiveness in the previously generated transgenic Atelp3-10 plants expressing a 35S:AtELP3 transgene, which complemented the morphological and disease susceptibility phenotypes of the Atelp3-10 mutant (DeFraia et al. 2013). We treated wild-type Col-0, Atelp3-10, and Atelp3-10 35S:AtELP3 plants with $\mathrm{NAD}^{+}$and analyzed $\mathrm{NAD}^{+}$-induced expression of $P R 1, R R 2$, and $P R 5$, as well as resistance to $P$. syringae pv. maculicola ES4326. As shown in Figure 3A to C, both $P R$ gene expression and $P$. syringae pv. maculicola ES4326 resistance were induced in the wild-type Col-0, and the induction was significantly inhibited in the Atelp3-10 mutant plants. Importantly, NAD ${ }^{+}$-induced $P R$ gene expression and $P$. syringae pv. maculicola ES4326 resistance were completely restored in the Atelp3-10 35S:AtELP3 plants (Fig. 3A to C). These results further unambiguously demonstrate that ELO3/AtELP3 is required for $\mathrm{NAD}^{+}$-induced defense responses.

\section{Mutations in the other five Elongator subunits} also inhibit exogenous $\mathrm{NAD}^{+}$-induced $P R$ gene expression and disease resistance.

To test whether the integrity of the Elongator complex is required for exogenous $\mathrm{NAD}^{+}$-activated defense signaling, we

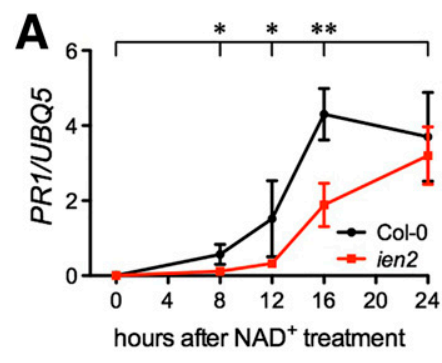

B

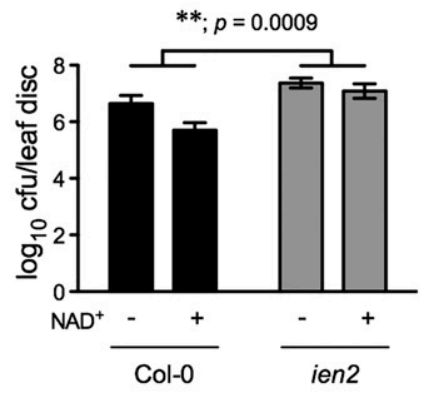

D

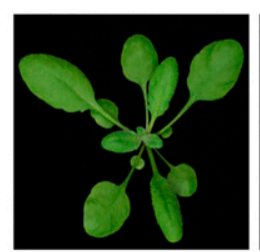

Col-0

ien2
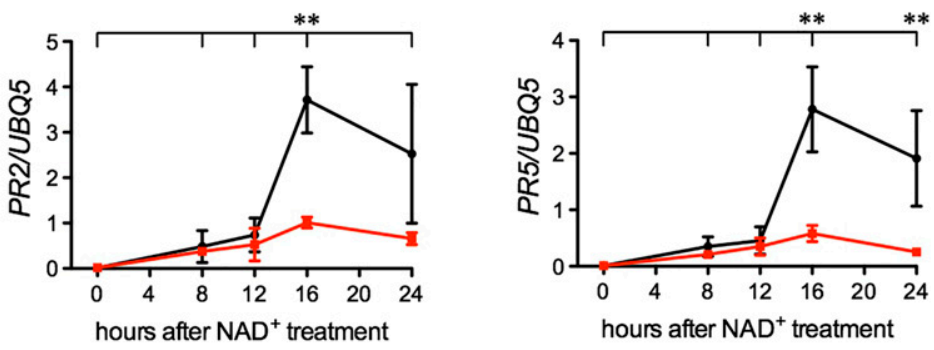

C

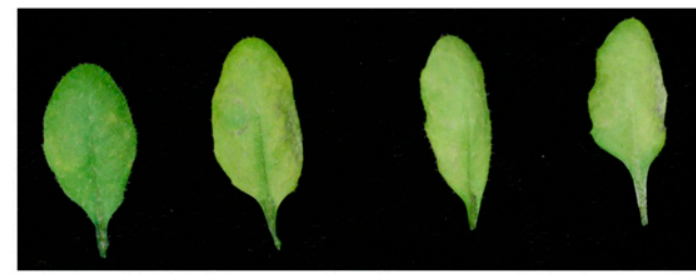

$\mathrm{NAD}^{+}+$

$\mathbf{F}$

$\mathbf{E}$

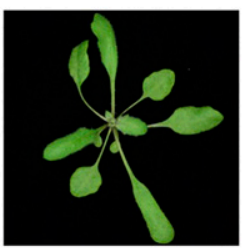

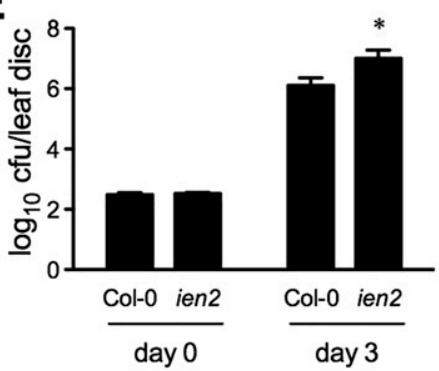

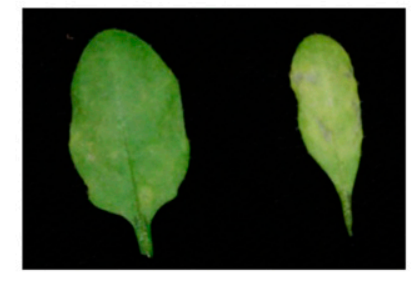

Col-0 ien2

Fig. 1. Characterization of the ien 2 mutant. A, Exogenous $\mathrm{NAD}^{+}$-induced expression of $P R 1, P R 2$, and $P R 5$ in ien 2 and wild-type Col-0 plants. Leaves of fourweek-old soil-grown plants were treated with $1 \mathrm{mM} \mathrm{NAD}{ }^{+}$solution. Total RNA was extracted from leaf tissues collected at the indicated time points and was subjected to real-time quantitative polymerase chain reaction analysis. Expression was normalized against constitutively expressed $U B Q 5$. Data represents the mean of three independent samples with standard deviation (SD). Asterisks indicate that the difference between the induction (the indicated time point versus $0 \mathrm{~h}$ ) of the gene in ien 2 and the wild-type Col- 0 plants was significant (two-way analysis of variance [ANOVA]; $*=P<0.05, * *=P<0.01$ ). The experiment was repeated twice with similar trends. B, Exogenous NAD ${ }^{+}$-induced resistance to Pseudomonas syringae pv. maculicola ES4326 in ien 2 and wild-type Col-0 plants. Leaves of four-week-old soil-grown plants were infiltrated with (+) or without $(-) 1 \mathrm{mM} \mathrm{NAD}^{+}$solution. Five hours later, the infiltrated leaves were inoculated with a $P$. syringae pv. maculicola ES4326 suspension (optical density at $600 \mathrm{~nm}\left[\mathrm{OD}_{600}\right]=0.001$ ). The in planta bacterial titers were determined at 3 days postinoculation (dpi). Data represent the mean of eight independent samples with SD. The asterisks indicate that the difference between the induction ( $\mathrm{NAD}^{+}$treated versus nontreated) of resistance to $P$. syringae pv. maculicola ES4326 in ien 2 and the wild-type Col-0 plants was significant (twoway ANOVA, $P<0.01$ ). The experiment was repeated three times with similar trends. C, Disease symptoms caused by $P$. syringae pv. maculicola ES4326 on ien2 and wild-type Col-0 leaves treated with (+) and without $(-) \mathrm{NAD}^{+}$. The experiment was carried out as in $\mathrm{B}$. Photos were taken at 3 days postinoculation (dpi). D, Morphology of four-week-old soil-grown ien2 and wild-type Col-0 plants. E, Susceptibility of ien 2 and wild-type Col-0 plants to P. syringae pv. maculicola ES4326. Four-week-old soil-grown plants were inoculated with a low dose of P. syringae pv. maculicola ES4326 (optical density at $600 \mathrm{~nm}=0.0001$ ). The in planta bacterial titers were determined immediately and at $3 \mathrm{dpi}$. Data represent the mean of eight independent samples with SD. The asterisk shows that $P$. syringae pv. maculicola ES4326 grew significantly more in ien 2 than in the wild-type Col- 0 plants (Student's $t$ test, $P<0.05$ ) The experiment was repeated three times with similar trends. F, Disease symptoms caused by $P$. syringae pv. maculicola ES4326 on ien 2 and wild-type Col-0 leaves. The experiment was carried out as in E. 
attempted to compare exogenous $\mathrm{NAD}^{+}$-induced defense responses in mutants of all six Elongator subunits. To this end, we used the mutant alleles elo2/Atelp1 (SALK_004690), Atelp2-2 (SALK_106485), elo3-6(GABI_555H06), elol/Atelp4 (SALK_ 079193), Atelp5 (GABI_700A12), and Atelp6 (SAIL_621_B08) for the six subunits, respectively. All these mutants are in Col-0 genetic background. Atelp2-2 (SALK_106485), elo3-6 (GABI_ 555H06), and elo1/Atelp4 (SALK_079193) have previously been described (DeFraia et al. 2010; Nelissen et al. 2010; Zhou et al. 2009). elo2/Atelp1 (SALK_004690) and Atelp6 (SAIL_ 621_B08) are new alleles of the reported elo2/Atelp1 and Atelp6 mutants, respectively (Chen et al. 2006; Nelissen et al. 2005). Mutants for the fifth subunit AtELP5 have not previously been characterized. We isolated a homozygous T-DNA insertion Atelp5 (GABI_700A12) mutant for this study. Real-time quantitative (q)PCR analysis revealed that, compared with the wild-type Col-0, expression of ELO2/AtELP1, AtELP2, ELO3/AtELP3, ELO1/AtELP4, AtELP5, and AtELP6 was significantly reduced in the corresponding T-DNA insertion lines (Supplementary Fig. S2), indicating that they are either knockout or knockdown mutants.

The morphological phenotypes of elo2/Atelp1, Atelp2, elo3/Atelp3, elo1/Atelp4, and Atelp6 have been separately described in previous studies (Chen et al. 2006; DeFraia et al. 2010, 2013; Nelissen et al. 2005, 2010; Zhou et al. 2009). When grown side by side, these mutants and Atelp5 all exhibited similar morphological phenotypes including elongated and curly leaves with a lighter shade of green than the wild-type Col-0 (Supplementary Fig. S3). Compared with each other, the elol/Atelp4 and Atelp5 mutants displayed the most and least
A chr. 5

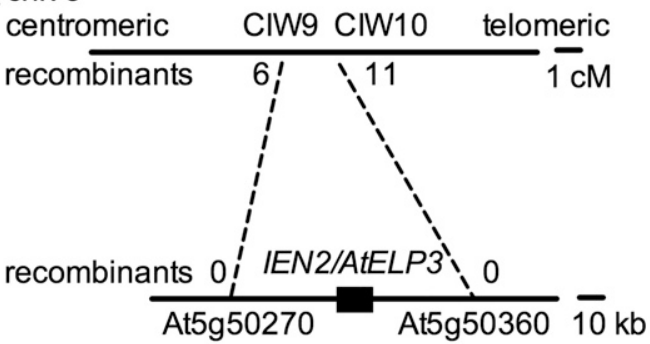

C

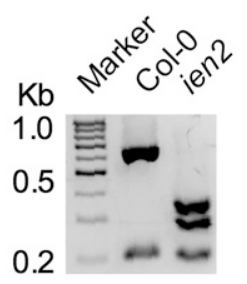

D

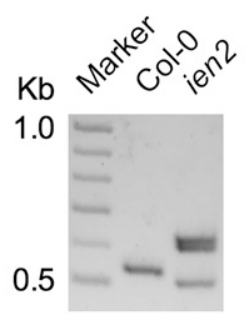

B

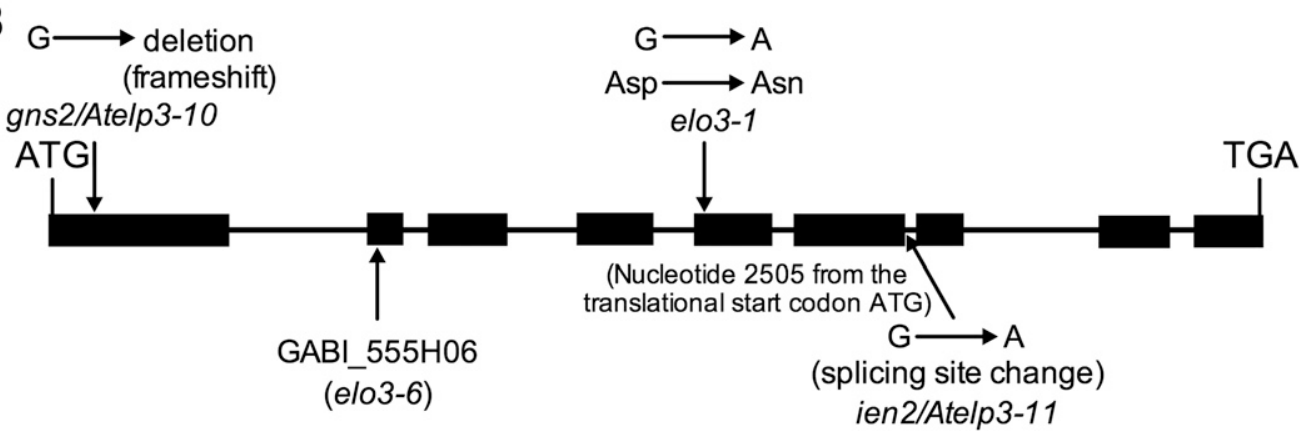

$\mathbf{E}$
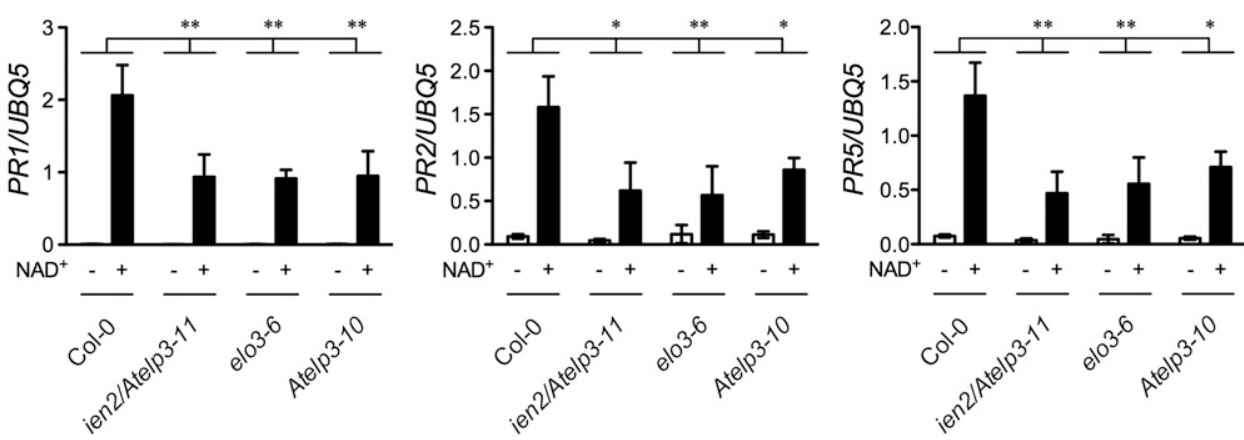

Fig. 2. Map-based cloning of ien2. A, A schematic diagram of the map-based cloning process. A total of $107 \mathrm{~F}_{2}$ progeny from a cross between ien 2 and ecotype Landsberg erecta, which exhibited ien 2 morphology, were used to determine the approximate position of the ien 2 mutation by bulked segregant analysis. The ien 2 mutation was linked to molecular markers CIW9 and CIW10 on chromosome 5. No recombinants were found for two markers located at the genetic loci At5g50270 and At5g50360. B, The structure of the ELO3/AtELP3 gene (At5g50320) and the positions of the gns2/Atelp3-10, elp3-6 (GABI_555H06), elo3-1, and ien 2 mutations. Boxes denote exons and lines between boxes denote introns. C, A cleaved amplified polymorphic sequences marker for the ien 2 mutation. Polymerase chain reaction (PCR) products amplified with a pair of primers (5'-TACACAAAGGCACATGCTTAC-3' and 5' ${ }^{\prime}$-TATCCCACCCTTGTGATCCG- $3^{\prime}$ ) from ien 2 and wild-type Col-0 genomic DNA were digested with DpnII and were separated in a 2\% agarose gel. Two bands (621 and $198 \mathrm{bp}$ ) and three bands (340, 281, and 198 bp) were detected for Col-0 and ien2, respectively. D, Abnormal splicing in the ien 2 mutant. A pair of primers (5'-GATGCCTGATCTTCCTAATG-3' and 5'-CATGAGTTCTGGACACGTTAC-3') spanning the mutation site was used to amply from wild-type Col-0 and ien 2 cDNA. The resulting PCR products were separated in a $2 \%$ agarose gel. Whereas a single band (544 bp) was amplified from the Col-0 cDNA, three bands with different sizes were amplified from the ien 2 cDNA. E, Exogenous NAD ${ }^{+}$-induced expression of $P R 1, P R 2$, and $P R 5$ in wild-type Col-0, elo3-6, Atelp3-10, and ien 2 plants. Leaves of four-week-old soilgrown plants were infiltrated with (+) or without $(-) 1 \mathrm{mM} \mathrm{NAD}^{+}$solution. Total RNA was extracted from infiltrated leaf tissues collected at $16 \mathrm{~h}$ postinoculation and was subjected to real-time quantitative PCR analysis. Expression was normalized against constitutively expressed UBQ5. Data represents the mean of three independent samples with standard deviation. An asterisks indicates that the difference between the induction (NAD ${ }^{+}$treated versus nontreated) of the $P R$ gene in the mutant and the wild-type Col-0 plants was significant (two-way analysis of variance, ${ }^{*}=P<0.05,{ }^{*}=P<0.01$ ). The experiment was repeated twice with similar trends. 
severe morphological phenotypes, respectively, suggesting some differences among the elolAtelp mutants.

To test whether mutations in each of the Elongator subunits affect exogenous $\mathrm{NAD}^{+}$-induced defense responses, we monitored $\mathrm{NAD}^{+}$-induced $P R$ gene expression and resistance to $P$. syringae pv. maculicola ES4326 in elo/Atep and wild-type Col-0 plants. As shown in Figure 4A, exogenous $\mathrm{NAD}^{+}$-induced expression of $P R 1, P R 2$, and PR5 was significantly reduced in all elolAtelp mutants compared with the wild-type Col-0. Similarly, exogenous $\mathrm{NAD}^{+}$-induced resistance to $P$. syringae pv. maculicola ES4326 was also significantly suppressed in all elo/Atelp mutants compared with the wild-type Col-0 (Fig. 4B and C). These results demonstrate that all six subunits of the Elongator complex are required for exogenous $\mathrm{NAD}^{+}$-induced defense responses in Arabidopsis.

\section{DISCUSSION}

Although our previous work has shown that exogenous $\mathrm{NAD}^{+}$induces defense responses in Arabidopsis (Zhang and Mou 2009), the signaling components in $\mathrm{NAD}^{+}$-induced defense signaling pathways remain to be fully discovered. In a genetic screen for Arabidopsis mutants insensitive to exogenous NAD ${ }^{+}$ (ien), we isolated a mutant named ien2. Map-based cloning revealed that the ien 2 mutation is located in the ELO3/AtELP3 gene, which encodes a subunit of the Elongator complex. Previously, we have shown that the Elongator subunits AtELP2 and ELO3/AtELP3 are required for basal resistance against both virulent and avirulent bacterial pathogens (DeFraia et al. 2010, 2013). We found that the other four subunits, ELO2/AtELP1, ELO1/AtELP4, AtELP5, and AtELP6, are also required for resistance to the avirulent bacterial pathogen $P$. syringae pv. tomato DC3000/avrRpt2 (Supplementary Fig. S4A) and that mutations in all six Elongator subunits reduced $P$. syringae pv. tomato DC3000/avrRpt2-induced ion leakage, indicating that the Elongator complex is required for full induction of a hypersensitive response. Furthermore, we have recently reported that ELO2/AtELP1, AtELP2, ELO3/AtELP3, ELO1/AtELP4, and AtELP5 are essential for resistance to necrotrophic fungal pathogens (Wang et al. 2015). These results suggest that the Elongator complex is likely important for general defense responses in plants. In this study, by characterizing different Elongator subunit mutants, we demonstrate that the Elongator complex plays a critical positive role in exogenous $\mathrm{NAD}^{+}$-induced defense responses in Arabidopsis.

Elongator is a six-subunit protein complex and loss of any subunit generally renders the complex inactive (Glatt et al. 2012; Versées et al. 2010). However, it has been reported that

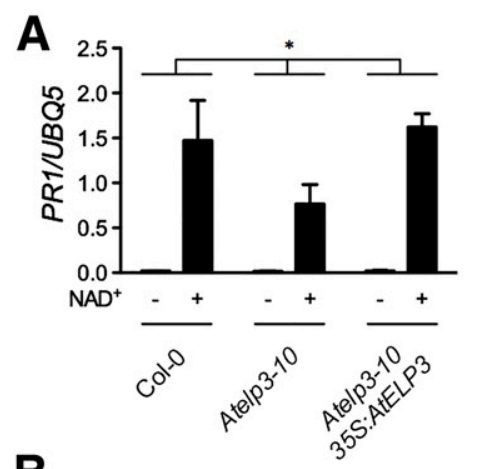

B

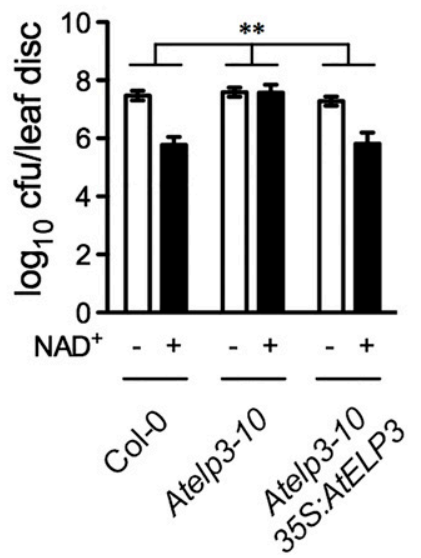

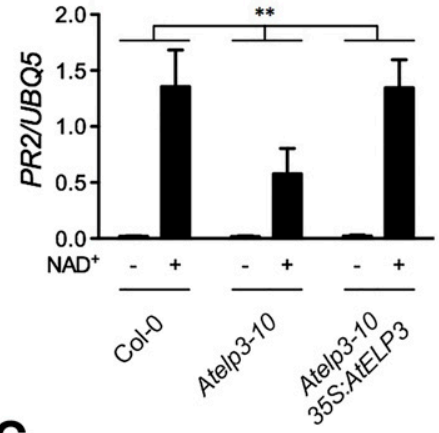

C
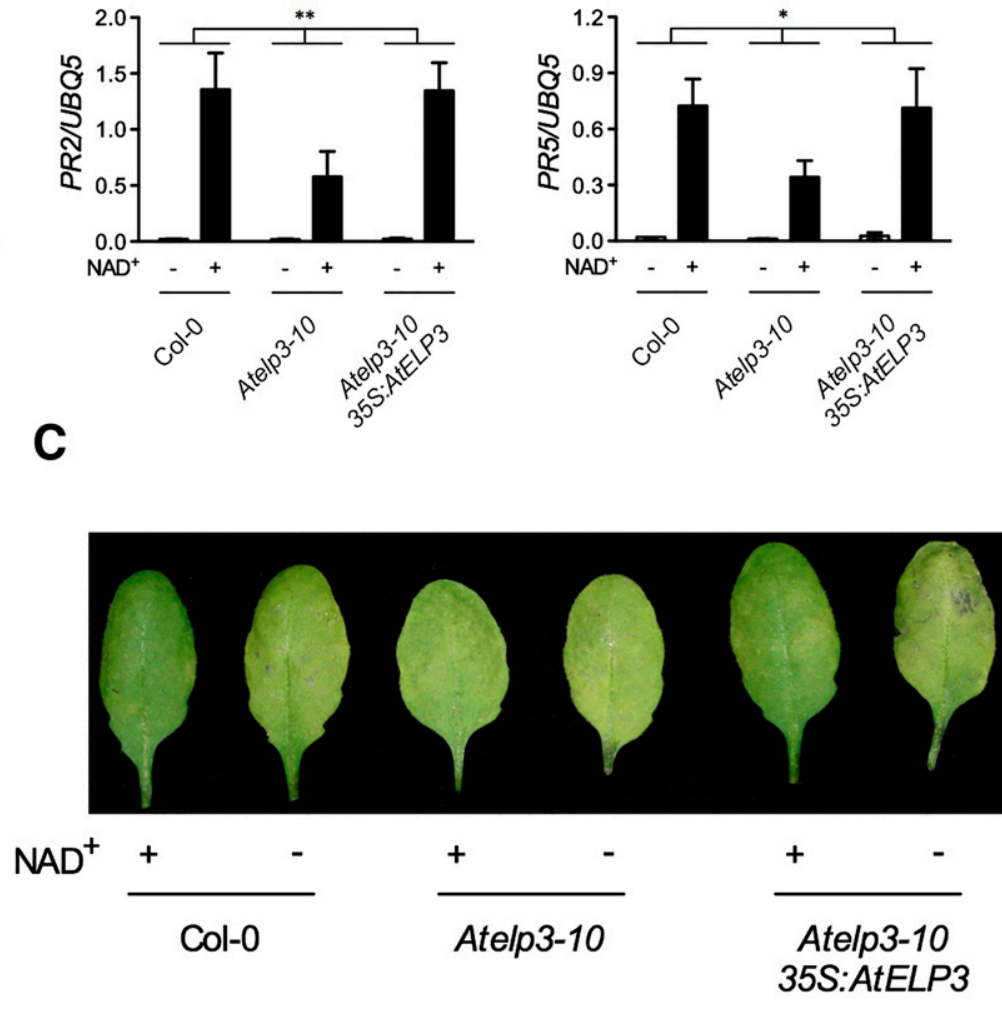

Fig. 3. Complementation of the Atelp3-10 mutation restores NAD ${ }^{+}$responsiveness. A, Exogenous NAD ${ }^{+}$-induced expression of $P R 1, P R 2$, and $P R 5$ in wildtype Col-0, Atelp3-10, and Atelp3-10 35S:AtELP3 plants. Leaves of four-week-old soil-grown plants were infiltrated with (+) or without (-) 1 mM NAD ${ }^{+}$ solution. Total RNA was extracted from the infiltrated leaf tissues collected at $16 \mathrm{~h}$ postinoculation and were subjected to real-time quantitative polymerase chain reaction analysis. Expression was normalized against constitutively expressed $U B Q 5$. Data represents the mean of three independent samples with standard deviation (SD). Asterisks indicate that the difference between the induction (NAD ${ }^{+}$treated versus nontreated) of the $P R$ gene in Atelp3-10 and the wild-type Col-0 or Atelp3-10 35S:AtELP3 plants was significant (two-way analysis of variance [ANOVA], $*=P<0.05$, $* * P=<0.01$ ). The experiment was repeated twice with similar trends. B, Exogenous NAD ${ }^{+}$-induced resistance to Pseudomonas syringae pv. maculicola ES4326 in wild-type Col-0, Atelp3-10, Atelp3-10 35S:AtELP3 plants. Leaves of four-week-old soil-grown plants were infiltrated with (+) or without (-) 1 mM NAD ${ }^{+}$solution. Five hours later, the infiltrated leaves were inoculated with a $P$. syringae pv. maculicola ES4326 suspension (optical density at $600 \mathrm{~nm}=0.001$ ). The in planta bacterial titers were determined at 3 days postinoculation (dpi). Data represent the mean of eight independent samples with SD. The asterisks show that the difference between the induction (NAD ${ }^{+}$treated versus nontreated) of resistance to P. syringae pv. maculicola ES4326 in Atelp-10 and the wild-type Col-0 or Atelp3-10 35S:AtELP3 plants was significant (two-way ANOVA, $P<0.01$ ). The experiment was repeated three times with similar trends. C, Disease symptoms caused by $P$. syringae pv. maculicola ES4326 on wild-type Col-0, Atelp3-10, and Atelp3-10 35S:AtELP3 leaves treated with (+) and without (-) NAD ${ }^{+}$. The experiment was carried out as in B. Photos were taken at 3 dpi. 
mutations in the core subcomplex subunits ELO2/AtELP1 and AtELP2 but not in the accessory subcomplex subunits ELO1/AtELP4 and AtELP6 lead to abscisic acid hypersensitivity in stomatal closure (Zhou et al. 2009), suggesting independent roles for the two subcomplexes in Arabidopsis. Previous studies have shown that mutants of ELO2/AtELP1, AtELP2, ELO3/AtELP3, ELO1/AtELP4, and AtELP6 have similar morphological phenotypes including chlorosis and developmental alterations (Chen et al. 2006; DeFraia et al. 2010, 2013; Nelissen et al. 2005, 2010; Zhou et al. 2009), indicating that the Elongator complex is essential not only for immunity but also for general plant fitness. The Atelp5 T-DNA insertion mutant isolated in this study is also morphologically similar to other elo/Atelp mutants, although its morphology is less severe than others, suggesting that the Elongator complex functions as a whole in plant growth and development. Since exogenous $\mathrm{NAD}^{+}$-induced $P R$ gene expression and resistance to $P$. syringae pv. maculicola ES4326 were similarly inhibited in mutants of all six Elongator subunits (Fig. 4A to C), the integrity of Elongator is also crucial for exogenous $\mathrm{NAD}^{+}$-induced defense responses.

We have previously shown that mutations in the Mediator complex subunits MED14/SWP and MED16/SFR6/IEN1 block exogenous $\mathrm{NAD}^{+}$-induced $P R$ gene expression and compromise SAR, suggesting that the Mediator tail module may integrate exogenous $\mathrm{NAD}^{+}$-activated signals into the RNAPII transcription machinery in Arabidopsis (Zhang et al. 2012,
2013). Mediator mostly functions at the transcription initiation stage, and different Mediator subunits act as adaptors for specific transcription factors of various signaling pathways, whereas Elongator is a general transcription regulator functioning at the elongation stage of transcription through interacting with hyperphosphorylated (elongating) RNAPII (Conaway and Conaway 2011; Hawkes et al. 2002; Nelissen et al. 2010; Otero et al. 1999; Wittschieben et al. 1999). Therefore, Elongatormediated transcription elongation may contribute to exogenous $\mathrm{NAD}^{+}$-induced defense gene transcription. These results together demonstrate the importance of the general transcription machinery in exogenous $\mathrm{NAD}^{+}$-induced defense signaling. Furthermore, it has previously been shown that, in plant cell proliferation, the Elongator complex is genetically positioned downstream of Mediator, which is consistent with their roles in the process of RNAPII-mediated transcription (Nelissen et al. 2005). As both Mediator and Elongator function in exogenous $\mathrm{NAD}^{+}$-activated defense gene transcription, it would be interesting to test whether the same epistatic relationship exists for Elongator and Mediator in $\mathrm{NAD}^{+}$-induced defense responses.

Elongator has been shown to function in histone acetylation and, one or both, DNA demethylation and methylation (Nelissen et al. 2010; Okada et al. 2010; Wang et al. 2013; Winkler et al. 2002). Although no intrinsic histone acetyltransferase and DNA demethylase activities have been reported for the Arabidopsis Elongator complex (Ding and Mou 2015), it has been shown

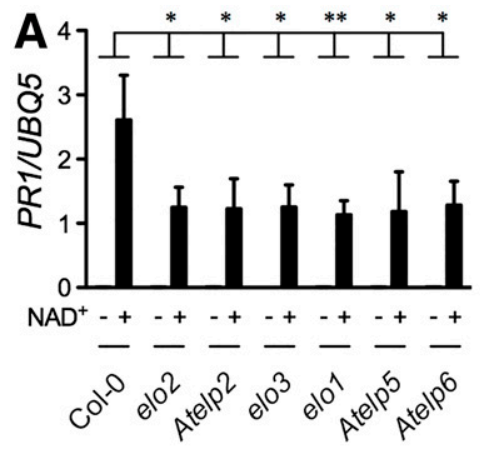

B

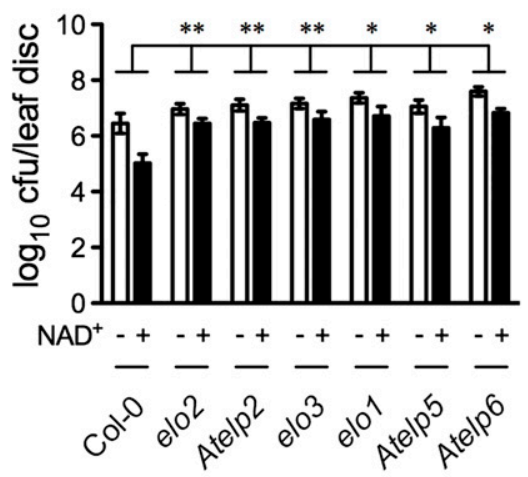

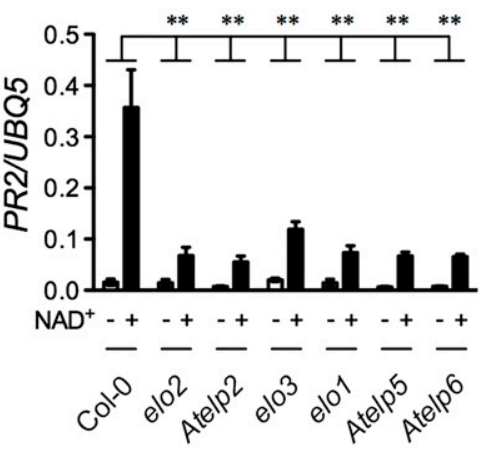

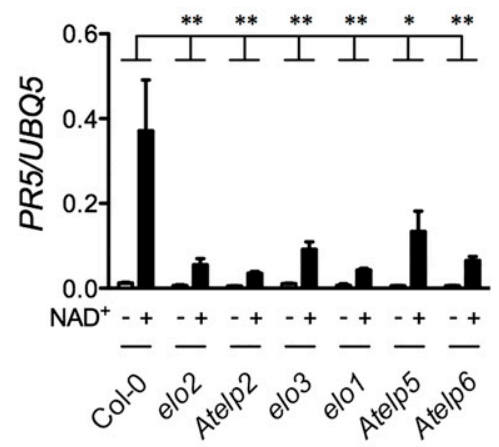

C

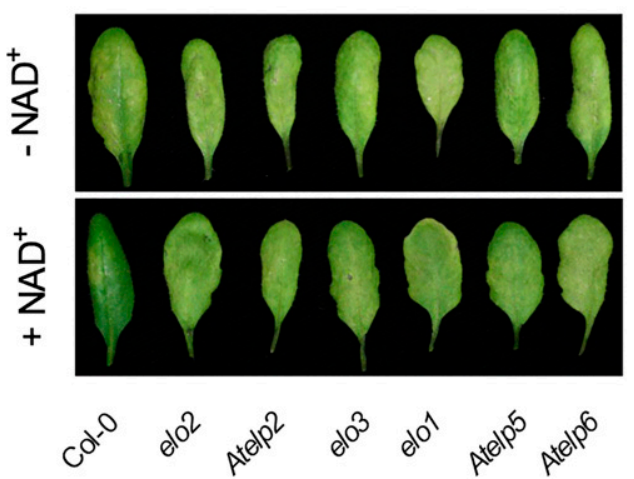

Fig. 4. NAD ${ }^{+}$-induced defense responses in mutants of all six Elongator subunits. A, Exogenous NAD ${ }^{+}$-induced expression of $P R 1, P R 2$, and $P R 5$ in wild-type Col-0 and elo/Atelp mutant plants. Leaves of four-week-old soil-grown plants were infiltrated with (+) or without (-) 1 mM NAD ${ }^{+}$solution. Total RNA was extracted from the infiltrated leaf tissues collected at $16 \mathrm{~h}$ postinoculation and was subjected to real-time quantitative polymerase chain reaction analysis. Expression was normalized against constitutively expressed UBQ5. Data represents the mean of three independent samples with standard deviation (SD). Asterisks indicate that the difference between the induction (NAD ${ }^{+}$treated versus nontreated) of the $P R$ gene in the mutant and the wild-type Col- 0 was significant (two-way analysis of variance [ANOVA], $*=P<0.05, * *=P<0.01$ ). The experiment was repeated twice with similar trends. B, Exogenous NAD ${ }^{+}-$ induced resistance to Pseudomonas syringae pv. maculicola ES4326 in elo/Atelp and wild-type Col-0 plants. Leaves of four-week-old soil-grown plants were infiltrated with (+) or without (-) $1 \mathrm{mM} \mathrm{NAD}^{+}$solution. Five hours later, the infiltrated leaves were inoculated with a $P$. syringae pv. maculicola ES4326 suspension (optical density at $600 \mathrm{~nm}=0.001$ ). The in planta bacterial titers were determined at 3 days postinoculation (dpi). Data represent the mean of eight independent samples with SD. Asterisks show that the difference between the induction (NAD ${ }^{+}$treated versus nontreated) of resistance to $P$. syringae pv. maculicola ES4326 in the mutant and the wild-type Col-0 was significant (two-way ANOVA, $*=P<0.05, * *=P<0.01$ ). The experiment was repeated three times with similar trends. C, Disease symptoms caused by $P$. syringae pv. maculicola ES4326 on elo/Atelp and wild-type Col-0 leaves treated with (+) and without (-) $\mathrm{NAD}^{+}$. The experiment was carried out as in C. Photos were taken at 3 dpi. 
that histone acetylation levels and DNA methylation profiles at specific genomic regions are altered in several Arabidopsis elo/Atelp mutants (Jia et al. 2015; Nelissen et al. 2010; Wang et al. 2013, 2015; Xu et al. 2012). We previously reported that a mutation in AtELP2 either reduces histone acetylation levels, alters DNA methylation landscape in several defense genes including NONEXPRESSER OF PR GENES1 (NPR1), PR2, and $P R 5$, or both (Wang et al. 2013). The altered chromatin structure may be responsible for the delayed or decreased induction of $P R$ genes after $\mathrm{NAD}^{+}$treatment and pathogen infection in elo/Atelp mutants (Figs. 1A and 4A) (DeFraia et al. 2010, 2013; Wang et al. 2013). Therefore, Elongator-mediated histone acetylation and one or both DNA demethylation and methylation may also contribute to exogenous $\mathrm{NAD}^{+}$-induced defense gene expression. Additionally, given the multifunctional nature of Elongator, this protein complex might also contribute to exogenous $\mathrm{NAD}^{+}$-activated defense signaling at the translational level by regulating tRNA modification (Esberg et al. 2006; Mehlgarten et al. 2010; Versées et al. 2010). On the other hand, similarly to Elongator, several proteins regulating histone acetylation and DNA methylation have been shown to function in plant defense responses (Agorio and Vera 2007; Choi et al. 2012; Devoto et al. 2002; Dowen et al. 2012; Kim et al. 2008; López et al. 2011; Luna et al. 2012; Wang et al. 2010; Yu et al. 2013; Zhou et al. 2005; Zhu et al. 2011). It would be interesting to test whether these epigenetic regulators play a role in exogenous $\mathrm{NAD}^{+}$-mediated defense pathways by using Arabidopsis histone acetylation and DNA methylation mutants.

Thus far, we have identified $\mathrm{Ca}^{2+}$, SA, NPR1, two Mediator subunits (MED14 and MED16), and the Elongator complex as signaling components downstream of exogenous $\mathrm{NAD}^{+}$(Fig. 4A to C) (Zhang and Mou 2009; Zhang et al. 2012, 2013). Since exogenously added $\mathrm{NAD}^{+}$most likely acts in the extracellular compartment (Zhang and Mou 2009), these components should also function in endogenous eNAD-mediated signaling pathways. However, although we have shown that expression of the human NAD(P)-metabolizing ectoenzyme CD38 inhibits SAR induction in Arabidopsis (Zhang and Mou 2012), it is still uncertain whether endogenous eNAD functions as an elicitor in plants. In this regard, identification of plasma membranelocated eNAD receptors would help address the uncertainty.

\section{MATERIALS AND METHODS}

\section{Plant material and growth conditions.}

The wild type used was the Arabidopsis thaliana (L.) Heynh. Columbia (Col-0) ecotype and the mutant alleles used in this study are listed in Supplementary Table S1. The complementation line Atelp3-10 35S:AtELP3 has previously been reported (DeFraia et al. 2013). Homozygous T-DNA insertion mutants were confirmed with primers flanking the T-DNA insertion sites (Supplementary Table S2) and the left border primers LBa1 and LB3 (Alonso et al. 2003; Sessions et al. 2002). Arabidopsis seeds were sown on autoclaved soil (Sunshine MVP, Sun Gro Horticulture, Agawam, MA, U.S.A.) and were vernalized at $4^{\circ} \mathrm{C}$ for 3 days. Plants were germinated and grown at approximately $23^{\circ} \mathrm{C}$ under a 16 -h-light and 8-h-dark regime. Four-week-old plants were used for all experiments.

\section{NAD treatment.}

$\beta$-NAD sodium salt (Sigma-Aldrich, St. Louis) was dissolved in water solution ( $1 \mathrm{mM}, \mathrm{pH} 6.0$, adjusted by $0.1 \mathrm{M} \mathrm{NaOH})$. The solution was infiltrated into Arabidopsis leaves using a 1-ml needleless syringe as previously described (Zhang and Mou 2009). For determination of $P R$ gene expression, infiltrated leaves were collected for RNA extraction $16 \mathrm{~h}$ after treatment or at indicated time points. For the disease resistance test, $5 \mathrm{~h}$ after
$\mathrm{NAD}^{+}$treatment, the infiltrated leaves were inoculated with the bacterial pathogen $P$. syringae pv. maculicola ES4326.

\section{Pathogen infection.}

Inoculation of plants with $P$. syringae pv. maculicola ES4326 was performed by pressure infiltration with a 1-ml needleless syringe, as described previously (Clarke et al. 1998). For the susceptibility test, a suspension of $P$. syringae pv. maculicola ES4326 (optical density at $600 \mathrm{~nm}\left[\mathrm{OD}_{600}\right]=0.0001$ ) was used, whereas for the $\mathrm{NAD}^{+}$-induced resistance assay, a suspension of $P$. syringae pv. maculicola ES4326 $\left(\mathrm{OD}_{600}=0.001\right)$ was used. Pathogen growth in the inoculated leaves was determined 2 to 3 days postinoculation.

\section{RNA analysis.}

RNA extraction, reverse transcription, and qPCR analysis were carried out as previously described (An and Mou 2012). The primers used for real-time qPCR analyses were listed in DeFraia et al. (2010) and Supplementary Table S3.

\section{Statistical methods.}

Statistical analyses were performed using data analysis tools in Excel, from Microsoft Office 2004 for Macintosh (Student's $t$ test: two samples assuming unequal variances), and the oneway and two-way analysis of variance in Prism 5.0b (GraphPad Software, La Jolla, CA, U.S.A.).

\section{Accession number}

Sequence data from this article can be found in the Arabidopsis Genome Initiative or GenBank/EMBL databases under the following accession numbers: ELO2/AtELP1 (At5g13680), AtELP2 (At1g49540), ELO3/AtELP3 (At5g50320), ELO1/AtELP4 (At3g11220), AtELP5 (At2g18410), AtELP6 (At4g10090), PR1 (At2g14610), PR2 (At3g57260), PR5 (At1g75040), and UBQ5 (At3g62250)

\section{ACKNOWLEDGMENTS}

We thank the Arabidopsis Biological Resource Center at The Ohio State University (Columbus, OH, U.S.A.) for SALK_004690, SALK_106485, SALK_079193, and SAIL_621_B08 seeds, and the European Arabidopsis Stock Centre at The University of Nottingham (Nottingham, U.K.) for GABI_555H06 and GABI_700A12 seeds. This work was supported by a grant from National Science Foundation (NSF IOS-0842716) awarded to Z. Mou.

\section{LITERATURE CITED}

Adams-Phillips, L., Briggs, A. G., and Bent, A. F. 2010. Disruption of poly(ADP-ribosyl)ation mechanisms alters responses of Arabidopsis to biotic stress. Plant Physiol. 152:267-280.

Adams-Phillips, L., Wan, J., Tan, X., Dunning, F. M., Meyers, B. C., Michelmore, R. W., and Bent, A. F. 2008. Discovery of ADP-ribosylation and other plant defense pathway elements through expression profiling of four different Arabidopsis-Pseudomonas R-avr interactions. Mol. PlantMicrobe Interact 21:646-657.

Agorio, A., and Vera, P. 2007. ARGONAUTE4 is required for resistance to Pseudomonas syringae in Arabidopsis. Plant Cell 19:3778-3790.

Alonso, J. M., Stepanova, A. N., Leisse, T. J., Kim, C. J., Chen, H., Shinn, P., Stevenson, D. K., Zimmerman, J., Barajas, P., Cheuk, R., Gadrinab, C., Heller, C., Jeske, A., Koesema, E., Meyers, C. C., Parker, H., Prednis, L., Ansari, Y., Choy, N., Deen, H., Geralt, M., Hazari, N., Hom, E., Karnes, M., Mulholland, C., Ndubaku, R., Schmidt, I., Guzman, P., Aguilar-Henonin, L., Schmid, M., Weigel, D., Carter, D. E., Marchand, T., Risseeuw, E., Brogden, D., Zeko, A., Crosby, W. L., Berry, C. C., and Ecker, J. R. 2003. Genome-wide insertional mutagenesis of Arabidopsis thaliana. Science 301:653-657.

An, C., and Mou, Z. 2012. Non-host defense response in a novel ArabidopsisXanthomonas citri subsp. citri pathosystem. PLoS One 7:e31130.

Anderson, S. L., Coli, R., Daly, I. W., Kichula, E. A., Rork, M. J., Volpi, S. A., Ekstein, J., and Rubin, B. Y. 2001. Familial dysautonomia is caused by mutations of the IKAP gene. Am. J. Hum. Genet. 68:753-758 
Bannas, P., Adriouch, S., Kahl, S., Braasch, F., Haag, F., and Koch-Nolte, F. 2005. Activity and specificity of toxin-related mouse T cell ecto-ADPribosyltransferase ART2.2 depends on its association with lipid rafts. Blood 105:3663-3670.

Bartsch, M., Gobbato, E., Bednarek, P., Debey, S., Schultze, J. L., Bautor, J., and Parker, J. E. 2006. Salicylic acid-independent ENHANCED DISEASE SUSCEPTIBILITY1 signaling in Arabidopsis immunity and cell death is regulated by the monooxygenase FMOI and the Nudix hydrolase NUDT7. Plant Cell 18:1038-1051.

Berger, F., Ramírez-Hernández, M. H., and Ziegler, M. 2004. The new life of a centenarian: Signalling functions of NAD $(\mathrm{P})$. Trends Biochem. Sci. 29:111-118

Billington, R. A., Bruzzone, S., De Flora, A., Genazzani, A. A., KochNolte, F., Ziegler, M., and Zocchi, E. 2006. Emerging functions of extracellular pyridine nucleotides. Mol. Med. 12:324-327.

Bruzzone, S., Moreschi, I., Guida, L., Usai, C., Zocchi, E., and De Flora, A. 2006. Extracellular $\mathrm{NAD}^{+}$regulates intracellular calcium levels and induces activation of human granulocytes. Biochem. J. 393:697-704.

Bürkle, A. 2001. Physiology and pathophysiology of poly(ADP-ribosyl)ation. BioEssays 23:795-806.

Ceni, C., Pochon, N., Brun, V., Muller-Steffner, H., Andrieux, A., Grunwald, D., Schuber, F., De Waard, M., Lund, F., Villaz, M., and Moutin, M. J. 2003. CD38-dependent ADP-ribosyl cyclase activity in developing and adult mouse brain. Biochem. J. 370:175-183.

Chen, Z., Zhang, H., Jablonowski, D., Zhou, X., Ren, X., Hong, X., Schaffrath, R., Zhu, J. K., and Gong, Z. 2006. Mutations in ABO1/ELO2, a subunit of holo-Elongator, increase abscisic acid sensitivity and drought tolerance in Arabidopsis thaliana. Mol. Cell. Biol. 26:69026912.

Choi, S. M., Song, H. R., Han, S. K., Han, M., Kim, C. Y., Park, J., Lee, Y. H., Jeon, J. S., Noh, Y. S., and Noh, B. 2012. HDA19 is required for the repression of salicylic acid biosynthesis and salicylic acid-mediated defense responses in Arabidopsis. Plant J. 71:135-146.

Clarke, J. D., Liu, Y., Klessig, D. F., and Dong, X. 1998. Uncoupling $P R$ gene expression from NPR1 and bacterial resistance: Characterization of the dominant Arabidopsis cpr6-1 mutant. Plant Cell 10:557-569.

Conaway, R. C., and Conaway, J. W. 2011. Function and regulation of the Mediator complex. Curr. Opin. Genet. Dev. 21:225-230.

Creppe, C., Malinouskaya, L., Volvert, M. L., Gillard, M., Close, P., Malaise, O., Laguesse, S., Cornez, I., Rahmouni, S., Ormenese, S., Belachew, S., Malgrange, B., Chapelle, J. P., Siebenlist, U., Moonen, G. Chariot, A., and Nguyen, L. 2009. Elongator controls the migration and differentiation of cortical neurons through acetylation of $\alpha$-tubulin. Cell 136:551-564.

De Flora, A., Zocchi, E., Guida, L., Franco, L., and Bruzzone, S. 2004. Autocrine and paracrine calcium signaling by the CD38/NAD ${ }^{+} /$cyclic ADP-ribose system. Ann. N. Y. Acad. Sci. 1028:176-191.

DeFraia, C., and Mou, Z. 2011. The role of the Elongator complex in plants. Plant Signal. Behav. 6:19-22.

DeFraia, C. T., Wang, Y., Yao, J., and Mou, Z. 2013. Elongator subunit 3 positively regulates plant immunity through its histone acetyltransferase and radical $S$-adenosylmethionine domains. BMC Plant Biol. 13:102.

DeFraia, C. T., Zhang, X., and Mou, Z. 2010. Elongator subunit 2 is an accelerator of immune responses in Arabidopsis thaliana. Plant J. 64:511523

Denu, J. M. 2003. Linking chromatin function with metabolic networks: Sir2 family of $\mathrm{NAD}^{+}$-dependent deacetylases. Trends Biochem. Sci. 28: 41-48.

Devoto, A., Nieto-Rostro, M., Xie, D., Ellis, C., Harmston, R., Patrick, E., Davis, J., Sherratt, L., Coleman, M., and Turner, J. G. 2002. COI1 links jasmonate signalling and fertility to the SCF ubiquitin-ligase complex in Arabidopsis. Plant J. 32:457-466.

Ding, Y., and Mou, Z. 2015. Elongator and its epigenetic role in plant development and responses to abiotic and biotic stresses. Front. Plant Sci. 6:296.

Djebbar, R., Rzigui, T., Pétriacq, P., Mauve, C., Priault, P., Fresneau, C., De Paepe, M., Florez-Sarasa, I., Benhassaine-Kesri, G., Streb, P., Gakière, B., Cornic, G., and De Paepe, R. 2012. Respiratory complex I deficiency induces drought tolerance by impacting leaf stomatal and hydraulic conductances. Planta 235:603-614.

Dowen, R. H., Pelizzola, M., Schmitz, R. J., Lister, R., Dowen, J. M., Nery, J. R., Dixon, J. E., and Ecker, J. R. 2012. Widespread dynamic DNA methylation in response to biotic stress. Proc. Natl. Acad. Sci. U.S.A. 109:E2183-E2191.

Dutilleul, C., Garmier, M., Noctor, G., Mathieu, C., Chétrit, P., Foyer, C. H., and de Paepe, R. 2003. Leaf mitochondria modulate whole cell redox homeostasis, set antioxidant capacity, and determine stress resistance through altered signaling and diurnal regulation. Plant Cell 15:1212-1226.
Dutilleul, C., Lelarge, C., Prioul, J. L., De Paepe, R., Foyer, C. H., and Noctor, G. 2005. Mitochondria-driven changes in leaf NAD status exert a crucial influence on the control of nitrate assimilation and the integration of carbon and nitrogen metabolism. Plant Physiol. 139:64-78.

Esberg, A., Huang, B., Johansson, M. J., and Byström, A. S. 2006. Elevated levels of two tRNA species bypass the requirement for Elongator complex in transcription and exocytosis. Mol. Cell 24:139-148.

Fonseca, J. P., and Dong, X. 2014. Functional characterization of a Nudix hydrolase AtNUDX8 upon pathogen attack indicates a positive role in plant immune responses. PLoS One 9:e114119.

Ford, K. A., Casida, J. E., Chandran, D., Gulevich, A. G., Okrent, R. A., Durkin, K. A., Sarpong, R., Bunnelle, E. M., and Wildermuth, M. C 2010. Neonicotinoid insecticides induce salicylate-associated plant defense responses. Proc. Natl. Acad. Sci. U.S.A. 107:17527-17532.

Ge, X., Li, G. J., Wang, S. B., Zhu, H., Zhu, T., Wang, X., and Xia, Y. 2007. AtNUDT7, a negative regulator of basal immunity in Arabidopsis, modulates two distinct defense response pathways and is involved in maintaining redox homeostasis. Plant Physiol. 145:204-215.

Glatt, S., Séraphin, B., and Müller, C. W. 2012. Elongator: Transcriptional or translational regulator? Transcription 3:273-276.

Han, M. K., Cho, Y. S., Kim, Y. S., Yim, C. Y., and Kim, U. H. 2000. Interaction of two classes of ADP-ribose transfer reactions in immune signaling. J. Biol. Chem. 275:20799-20805.

Hawkes, N. A., Otero, G., Winkler, G. S., Marshall, N., Dahmus, M. E., Krappmann, D., Scheidereit, C., Thomas, C. L., Schiavo, G., ErdjumentBromage, H., Tempst, P., and Svejstrup, J. Q. 2002. Purification and characterization of the human Elongator complex. J. Biol. Chem. 277: 3047-3052.

Huang, B., Johansson, M. J., and Byström, A. S. 2005. An early step in wobble uridine tRNA modification requires the Elongator complex. RNA 11:424-436.

Hunt, L., Lerner, F., and Ziegler, M. 2004. NAD-new roles in signaling and gene regulation in plants. New Phytol. 163:31-44.

Ishikawa, K., Yoshimura, K., Harada, K., Fukusaki, E., Ogawa, T., Tamoi, M., and Shigeoka, S. 2010. AtNUDX6, an ADP-ribose/NADH pyrophosphohydrolase in Arabidopsis, positively regulates NPR1-dependent salicylic acid signaling. Plant Physiol. 152:2000-2012.

Jablonowski, D., Frohloff, F., Fichtner, L., Stark, M. J., and Schaffrath, R. 2001. Kluyveromyces lactis zymocin mode of action is linked to RNA polymerase II function via Elongator. Mol. Microbiol. 42:1095-1105.

Jacobson, M. K., and Jacobson, E. L. 1999. Discovering new ADP-ribose polymer cycles: Protecting the genome and more. Trends Biochem. Sci. 24:415-417.

Jia, Y., Tian, H., Li, H., Yu, Q., Wang, L., Friml, J., and Ding, Z. 2015. The Arabidopsis thaliana Elongator complex subunit 2 epigenetically affects root development. J. Exp. Bot. 66:4631-4642.

Judkins, C. P., Sobey, C. G., Dang, T. T., Miller, A. A., Dusting, G. J., and Drummond, G. R. 2006. NADPH-induced contractions of mouse aorta do not involve NADPH oxidase: A role for P2X receptors. J. Pharmacol. Exp. Ther. 317:644-650.

Kim, K. C., Lai, Z., Fan, B., and Chen, Z. 2008. Arabidopsis WRKY38 and WRKY62 transcription factors interact with histone deacetylase 19 in basal defense. Plant Cell 20:2357-2371.

Krebs, C., Adriouch, S., Braasch, F., Koestner, W., Leiter, E. H., Seman, M. Lund, F. E., Oppenheimer, N., Haag, F., and Koch-Nolte, F. 2005. CD38 controls ADP-ribosyltransferase-2-catalyzed ADP-ribosylation of $\mathrm{T}$ cell surface proteins. J. Immunol. 174:3298-3305.

Krogan, N. J., and Greenblatt, J. F. 2001. Characterization of a six-subunit holo-Elongator complex required for the regulated expression of a group of genes in Saccharomyces cerevisiae. Mol. Cell. Biol. 21:8203-8212.

Lee, H. C. 2001. Physiological functions of cyclic ADP-ribose and NAADP as calcium messengers. Annu. Rev. Pharmacol. Toxicol. 41:317-345.

López, A., Ramírez, V., García-Andrade, J., Flors, V., and Vera, P. 2011. The RNA silencing enzyme RNA polymerase $\mathrm{v}$ is required for plant immunity. PLoS Genet. 7:e1002434.

Luna, E., Bruce, T. J. A., Roberts, M. R., Flors, V., and Ton, J. 2012. Nextgeneration systemic acquired resistance. Plant Physiol. 158:844-853.

Macho, A. P., Boutrot, F., Rathjen, J. P., and Zipfel, C. 2012. Aspartate oxidase plays an important role in Arabidopsis stomatal immunity. Plant Physiol. 159:1845-1856.

Malavasi, F., Deaglio, S., Ferrero, E., Funaro, A., Sancho, J., Ausiello, C. M., Ortolan, E., Vaisitti, T., Zubiaur, M., Fedele, G., Aydin, S., Tibaldi, E. V., Durelli, I., Lusso, R., Cozno, F., and Horenstein, A. L. 2006. CD38 and CD157 as receptors of the immune system: A bridge between innate and adaptive immunity. Mol. Med. 12:334-341.

Mehlgarten, C., Jablonowski, D., Wrackmeyer, U., Tschitschmann, S., Sondermann, D., Jäger, G., Gong, Z., Byström, A. S., Schaffrath, R., and Breunig, K. D. 2010. Elongator function in tRNA wobble uridine 
modification is conserved between yeast and plants. Mol. Microbiol. 76: 1082-1094.

Morabito, F., Damle, R. N., Deaglio, S., Keating, M., Ferrarini, M., and Chiorazzi, N. 2006. The CD38 ectoenzyme family: Advances in basic science and clinical practice. Mol. Med. 12:342-344.

Moreschi, I., Bruzzone, S., Nicholas, R. A., Fruscione, F., Sturla, L., Benvenuto, F., Usai, C., Meis, S., Kassack, M. U., Zocchi, E., and De Flora, A. 2006. Extracellular $\mathrm{NAD}^{+}$is an agonist of the human $\mathrm{P}_{2} \mathrm{Y}_{11}$ purinergic receptor in human granulocytes. J. Biol. Chem. 281:31419-31429.

Nelissen, H., De Groeve, S., Fleury, D., Neyt, P., Bruno, L., Bitonti, M. B., Vandenbussche, F., Van der Straeten, D., Yamaguchi, T., Tsukaya, H., Witters, E., De Jaeger, G., Houben, A., and Van Lijsebettens, M. 2010. Plant Elongator regulates auxin-related genes during RNA polymerase II transcription elongation. Proc. Natl. Acad. Sci. U.S.A. 107:1678-1683.

Nelissen, H., Fleury, D., Bruno, L., Robles, P., De Veylder, L., Traas, J., Micol, J. L., Van Montagu, M., Inzé, D., and Van Lijsebettens, M. 2005. The elongata mutants identify a functional Elongator complex in plants with a role in cell proliferation during organ growth. Proc. Natl. Acad. Sci. U.S.A. 102:7754-7759.

Nemoto, E., Yu, Y., and Dennert, G. 1996. Cell surface ADPribosyltransferase regulates lymphocyte function-associated molecule-1 (LFA-1) function in T cells. J. Immunol. 157:3341-3349.

Noctor, G., Queval, G., and Gakière, B. 2006. NAD(P) synthesis and pyridine nucleotide cycling in plants and their potential importance in stress conditions. J. Exp. Bot. 57:1603-1620.

Okada, Y., Yamagata, K., Hong, K., Wakayama, T., and Zhang, Y. 2010. A role for the Elongator complex in zygotic paternal genome demethylation. Nature 463:554-558.

Otero, G., Fellows, J., Li, Y., de Bizemont, T., Dirac, A. M., Gustafsson, C. M., Erdjument-Bromage, H., Tempst, P., and Svejstrup, J. Q. 1999. Elongator, a multisubunit component of a novel RNA polymerase II holoenzyme for transcriptional elongation. Mol. Cell 3:109-118.

Partidá-Sánchez, S., Rivero-Nava, L., Shi, G., and Lund, F. E. 2007. CD38: An ecto-enzyme at the crossroads of innate and adaptive immune responses. Adv. Exp. Med. Biol. 590:171-183.

Pétriacq, P., de Bont, L., Hager, J., Didierlaurent, L., Mauve, C., Guérard, F., Noctor, G., Pelletier, S., Renou, J. P., Tcherkez, G., and Gakière, B. 2012. Inducible NAD overproduction in Arabidopsis alters metabolic pools and gene expression correlated with increased salicylate content and resistance to Pst-AvrRpm1. Plant J. 70:650-665.

Pétriacq, P., de Bont, L., Tcherkez, G., and Gakière, B. 2013. NAD: Not just a pawn on the board of plant-pathogen interactions. Plant Signal. Behav. 8:e22477.

Rahl, P. B., Chen, C. Z., and Collins, R. N. 2005. Elp1p, the yeast homolog of the FD disease syndrome protein, negatively regulates exocytosis independently of transcriptional elongation. Mol. Cell 17:841-853.

Sánchez, J. P., Duque, P., and Chua, N. H. 2004. ABA activates ADPR cyclase and cADPR induces a subset of ABA-responsive genes in Arabidopsis. Plant J. 38:381-395.

Seman, M., Adriouch, S., Scheuplein, F., Krebs, C., Freese, D., Glowacki, G., Deterre, P., Haag, F., and Koch-Nolte, F. 2003. NAD-induced T cell death: ADP-ribosylation of cell surface proteins by ART2 activates the cytolytic P2X7 purinoceptor. Immunity 19:571-582.

Sessions, A., Burke, E., Presting, G., Aux, G., McElver, J., Patton, D., Dietrich, B., Ho, P., Bacwaden, J., Ko, C., Clarke, J. D., Cotton, D., Bullis, D., Snell, J., Miguel, T., Hutchison, D., Kimmerly, B., Mitzel, T., Katagiri, F., Glazebrook, J., Law, M., and Goff, S. A. 2002. A highthroughput Arabidopsis reverse genetics system. Plant Cell 14:29852994.

Slaugenhaupt, S. A., Blumenfeld, A., Gill, S. P., Leyne, M., Mull, J., Cuajungco, M. P., Liebert, C. B., Chadwick, B., Idelson, M., Reznik, L. Robbins, C., Makalowska, I., Brownstein, M., Krappmann, D., Scheidereit,
C., Maayan, C., Axelrod, F. B., and Gusella, J. F. 2001. Tissue-specific expression of a splicing mutation in the IKBKAP gene causes familial dysautonomia. Am. J. Hum. Genet. 68:598-605.

Versées, W., De Groeve, S., and Van Lijsebettens, M. 2010. Elongator, a conserved multitasking complex? Mol. Microbiol. 76:1065-1069.

Wang, C., Ding, Y., Yao, J., Zhang, Y., Sun, Y., Colee, J., and Mou, Z. 2015. Arabidopsis Elongator subunit 2 positively contributes to resistance to the necrotrophic fungal pathogens Botrytis cinerea and Alternaria brassicicola. Plant J. 83:1019-1033.

Wang, C., Gao, F., Wu, J., Dai, J., Wei, C., and Li, Y. 2010. Arabidopsis putative deacetylase AtSRT2 regulates basal defense by suppressing PAD4, EDS5 and SID2 expression. Plant Cell Physiol. 51:1291-1299.

Wang, Y., An, C., Zhang, X., Yao, J., Zhang, Y., Sun, Y., Yu, F., Amador, D. M., and Mou, Z. 2013. The Arabidopsis Elongator complex subunit2 epigenetically regulates plant immune responses. Plant Cell 25:762-776.

Winkler, G. S., Kristjuhan, A., Erdjument-Bromage, H., Tempst, P., and Svejstrup, J. Q. 2002. Elongator is a histone H3 and H4 acetyltransferase important for normal histone acetylation levels in vivo. Proc. Natl. Acad. Sci. U.S.A. 99:3517-3522.

Wittschieben, B. O., Otero, G., de Bizemont, T., Fellows, J., ErdjumentBromage, H., Ohba, R., Li, Y., Allis, C. D., Tempst, P., and Svejstrup, J. Q. 1999. A novel histone acetyltransferase is an integral subunit of elongating RNA polymerase II holoenzyme. Mol. Cell 4:123-128.

Xu, D., Huang, W., Li, Y., Wang, H., Huang, H., and Cui, X. 2012. Elongator complex is critical for cell cycle progression and leaf patterning in Arabidopsis. Plant J. 69:792-808.

Yu, A., Lepère, G., Jay, F., Wang, J., Bapaume, L., Wang, Y., Abraham, A. L., Penterman, J., Fischer, R. L., Voinnet, O., and Navarro, L. 2013. Dynamics and biological relevance of DNA demethylation in Arabidopsis antibacterial defense. Proc. Natl. Acad. Sci. U.S.A. 110:23892394.

Zhang, X., and Mou, Z. 2009. Extracellular pyridine nucleotides induce $P R$ gene expression and disease resistance in Arabidopsis. Plant J. 57: 302-312.

Zhang, X., and Mou, Z. 2012. Expression of the human NAD(P)metabolizing ectoenzyme CD38 compromises systemic acquired resistance in Arabidopsis. Mol. Plant-Microbe Interact 25:1209-1218.

Zhang, X., Wang, C., Zhang, Y., Sun, Y., and Mou, Z. 2012. The Arabidopsis mediator complex subunit16 positively regulates salicylatemediated systemic acquired resistance and jasmonate/ethylene-induced defense pathways. Plant Cell 24:4294-4309.

Zhang, X., Yao, J., Zhang, Y., Sun, Y., and Mou, Z. 2013. The Arabidopsis Mediator complex subunits MED14/SWP and MED16/SFR6/IEN1 differentially regulate defense gene expression in plant immune responses. Plant J. 75:484-497.

Zhou, C., Zhang, L., Duan, J., Miki, B., and Wu, K. 2005. HISTONE DEACETYLASE19 is involved in jasmonic acid and ethylene signaling of pathogen response in Arabidopsis. Plant Cell 17:1196-1204.

Zhou, X., Hua, D., Chen, Z., Zhou, Z., and Gong, Z. 2009. Elongator mediates ABA responses, oxidative stress resistance and anthocyanin biosynthesis in Arabidopsis. Plant J. 60:79-90.

Zhu, Z., An, F., Feng, Y., Li, P., Xue, L., Mu, A., Jiang, Z., Kim, J. M., To, T. K., Li, W., Zhang, X., Yu, Q., Dong, Z., Chen, W. Q., Seki, M., Zhou, J. M., and Guo, H. 2011. Derepression of ethylene-stabilized transcription factors (EIN3/EIL1) mediates jasmonate and ethylene signaling synergy in Arabidopsis. Proc. Natl. Acad. Sci. U.S.A. 108: 12539-12544.

Ziegler, M. 2005. A vital link between energy and signal transduction: Regulatory functions of NAD(P). FEBS (Fed. Eur. Biochem. Soc.) Lett. 272:4561-4564.

Zolkiewska, A. 2005. Ecto-ADP-ribose transferases: Cell-surface response to local tissue injury. Physiology (Bethesda) 20:374-381. 